\title{
Climate change over Leh (Ladakh), India
}

\author{
Article
}

Accepted Version

Chevuturi, A., Dimri, A. P. and Thayyen, R. J. (2018) Climate change over Leh (Ladakh), India. Theoretical and Applied Climatology, 131 (1-2). pp. 531-545. ISSN 1434-4483 doi: https://doi.org/10.1007/s00704-016-1989-1 Available at https://centaur.reading.ac.uk/68084/

It is advisable to refer to the publisher's version if you intend to cite from the work. See Guidance on citing.

Published version at: https://www.researchgate.net/publication/310023429_Climate_change_over_Leh_Ladakh_India To link to this article DOI: http://dx.doi.org/10.1007/s00704-016-1989-1

Publisher: Springer

All outputs in CentAUR are protected by Intellectual Property Rights law, including copyright law. Copyright and IPR is retained by the creators or other copyright holders. Terms and conditions for use of this material are defined in the End User Agreement.

\section{www.reading.ac.uk/centaur}

\section{CentAUR}

Central Archive at the University of Reading

Reading's research outputs online 


\title{
Climate Change over Leh (Ladakh), India
}

\author{
A. Chevuturi ${ }^{1}$, A. P. Dimri ${ }^{1, *}$, R.J. Thayyen ${ }^{2}$ \\ ${ }^{1}$ School of Environmental Sciences, Jawaharlal Nehru University, New Delhi, India \\ ${ }^{2}$ National Institute of Hydrology, WHRC, Jammu, India
}

*Corresponding Address: Prof. A. P. Dimri, School of Environmental Sciences, Jawaharlal Nehru University, New Delhi, 110067, India, Email: apdimri@hotmail.com

\begin{abstract}
Mountains over the world are considered as the indicators of climate change. The Himalayas is comprised of five ranges viz., Pir Panjal, Great Himalayas, Zanskar, Ladhak and Karakorum. Ladakh region lies in the northern most state of India, Jammu and Kashmir, in the Ladhak range. It has a unique cold-arid climate and lies immediately south of the Karakorum range. With scarce water resources, such regions show high sensitivity and vulnerability to the change in climate, and need urgent attention. The objective of this study is to understand the climate of the Ladakh region and to characterize its changing climate. Using different temperature and precipitation datasets over Leh and surrounding regions, we statistically analyze the current trends of climatic patterns over the region. The study shows that the climate over Leh shows a warming trend with reduced precipitation in the current decade. The reduced average seasonal precipitation might also be associated with some indications of reducing number of days with higher precipitation amounts over the region.
\end{abstract}

\section{Introduction}

The Himalayas are the highest mountain range/landmass of the world. This region is characterized by a complex topography and varied land-cover/land-use patterns. It has a significant influence on the weather and climatic patterns over the south Asian region (Kumar et 
al., 1999; Day and Bhanu Kumar, 1982). The Himalayan glaciers are storehouse of water and replenish the mountain rivers (Bookhagen and Burbank, 2010; Immerzeel, 2010, 2013; Kaser et al 2010). Himalayas influence climate at global, regional, local and micro scales and in turn the climate at all four scales impacts the Himalayan climate itself (Dimri and Niyogi, 2012). All of these factors combined, the changes occurring over the Himalayas have major impact on the climatology, hydrology and ecology of the Indian region.

Heterogeneous topography is a characteristic feature of mountainous regions and shows large variety of climatic conditions over a comparatively smaller gradient (Bhutiyani et al., 2007). Amplified variations in temperature and precipitation patterns are noted in such regions (Jhajharia and Singh, 2011). As these regions are most vulnerable to climate change (IPCC, 2007), they are used as indicators of change with focus on trends and consequences (UNEP, 2009). Higher sensitivity of mountainous regions towards the impacts of extreme variation in the climate makes such studies even more important.

Climate change is the one of the most debated topic in the recent decades. The causes of global warming trends are associated with the increase in green house gases and aerosols along with the changes in land cover and land use patterns (Bhutiyani et al., 2010; IPCC, 2013). Over the Himalayan region, changes in temperature and precipitation patterns and it impacts on water resources, glaciers, ecology and agriculture etc. are being attributed to the changing climate (Dimri and Dash, 2012; Shekhar et al., 2010). Different studies pertaining to climate change in the Himalayas have published dissimilar results. While Bhutiyani et al. (2007) and Dash et al. (2007) suggest increasing annual temperature trends, Yadav et al. (2004) show a pre-monsoon cooling. Trends in winter temperature are noted by Dimri and Dash (2012); Archer and Fowler (2004) and Jhajharia and Singh (2011) suggest an increaeduring monsoon and post monsoon 
seasons. However, as the Himalayas cover a vast spatial expanse therefore, its sub-regions respond differently to the climate change.

Out of the many projected consequences, changes in the intensity and frequency of extreme precipitation events are noted as an important impact (Shekhar et al., 2010). Yadav et al. (2010) predicted increasing temperature and precipitation patterns with increasing greenhouse gases and aerosol scenarios. With reference to extreme precipitation events, the Himalayas are most vulnerable due to orographic impact on the monsoon circulation flow. In case of an extreme event like a cloudburst, secondary impacts like flashfloods, glacier lake outburst flood and landslides etc. cause major devastation over the region (Dimri et al. 2016; Thayyen et al., 2013). This raises the question, are the extreme events increasing over the Himalayas due to the changing climate? Dash et al. (2007) and Nandargi and Dhar (2011) suggested an increase in the short duration high intensity precipitation events over the hilly regions of India. But with the variable topographical sub-regions as discussed above, how prudent it is to study the Himalayas as a whole? According to Bhutiyani et al. (2007) there is a clear non-uniformity of rates of change of temperature due to the physiographic characteristics of sub-regions. Keeping these factors in mind, the present study focuses on a Ladhak sub-region, the cold-arid region, of the Indian western Himalayas. This region is considered a rain shadow zone during Indian summer monsoon and Indian winter monsoon, with a low mean annual precipitation of $115 \mathrm{~mm}$ at Leh having cold temperatures (Thayyen et al., 2013). The area thus is cold and arid with lack of vegetation as a prominent feature, and is termed as a cold desert (Kumar et al., 2012).

There are very few climate studies conducted over Ladakh/Leh (Le Masson and Nair, 2012). Bhutiyani et al. (2007) showed increasing temperature trends over Leh for the period of 1901-1989, with greater increase noted after 1960s. Precipitation trends show a decreasing trend 
during winter and summer periods (Bhutiyani et al., 2010) with significant impact seen after 1990s. There is a need to analyze the precipitation trend over the years with specific emphasis on the extreme events. Thus, this study proposes a detailed analysis of climate over the Leh region and to further discuss its trend in the context of changing climate.

\section{Study area}

Present study is focused on the Ladakh region (Fig. S1a). Ladakh is a region bounded by the Karakoram range in the north and the Great Himalayan range in the south (Fig. S1b). Within its boundary it has two parallel ranges - the Ladakh range and Zanskar range - extending from north-west to south-east with the Indus River flowing in between them.. Ladakh district has two major cities, Leh and Kargil with Leh being the largest city. For a detailed topographical map of Ladakh (Leh and Kargil) please visit http://www.lib.utexas.edu/maps/ams/india/ni-43-08.jpg and http://www.lib.utexas.edu/maps/ams/india/ni-43-07.jpg respectively. In view of the recurring cloudburst event over Leh region (Thayyen et al., 2013), this study proposes a detailed analysis of climate patterns over the Leh region during the past few decades to comprehend the occurrence and impact of climate change over Leh as a representation of the Ladakh region.

Leh $\left(34^{\circ} 17^{\prime} \mathrm{N}\right.$ and $\left.77^{\circ} 58^{\prime} \mathrm{E}\right)$ is the district headquarter as well as the capital of Ladakh Autonomous Hill Council in the state of Jammu and Kashmir, India. The city is situated in the foothills of Ladakh range in the catchment of the Indus River and has an elevation of $3500 \mathrm{~m}$ a.s.l.. The Indus valley is bound by Ladakh range in the north and Zanskar range in the south as shown in the Fig. S1a and S1b.

\section{Data and Methodology}

To study the climatic features of a region the two main climatic variables recorded and analyzed are temperature and precipitation. In this paper, a regional analysis is attempted by 
taking advantage of the available in situ climate data at five stations covering a wide swath of the Ladakh region. Table 1 shows the different datasets used in this study. For temperature analysis eight different observational and reanalysis datasets have been used and described in detail in Table 1a. The three global reanalysis datasets (CRU, NCEP and ERA-Interim) have been used to derive the monthly mean temperature over Leh for the available time period as mentioned in Table 1. In situ temperature observations over Ladakh region at Leh and four other stations, viz., Base, Kargil, Khalsi and Base Camp, are used in this study. The Leh station dataset is provided by India Meteorological Department (IMD) for daily Maximum (Tmax, ${ }^{\circ} \mathrm{C}$ ) and Minimum Temperature (Tmin, ${ }^{\circ} \mathrm{C}$ ). The other four stations data is of the Indian Air Force which provides Maximum (Tmax, ${ }^{\circ} \mathrm{C}$ ) and Minimum Temperature $\left(\operatorname{Tmin},{ }^{\circ} \mathrm{C}\right.$ ) as the annual pentad time series. For precipitation analysis also eight different datasets are used, which are available as monthly precipitation or daily precipitation (Table 1b). In addition, gridded observational and reanalysis datasets for precipitation are described in detail in the Table 1b. The daily precipitation datasets are used to derive the monthly precipitation for those respective datasets. Other than these, India Meteorological Department (IMD) station data for Leh provides daily precipitation and Indian Air Force station data for Leh provides monthly precipitation is used. Seasonal time series has also been compiled from the daily and monthly datasets to get winter (December-JanuaryFebruary-March: DJFM), pre-monsoon (April-May-June: AMJ), monsoon (June-July-August: JJA) and post-monsoon (October-November: ON) data.

For analyzing the inter-annual, inter-seasonal and intra-annual climatic fluctuations in different datasets, various statistical tools have been implemented. As mentioned before, the daily datasets are used to derive the mean monthly values which further used to derive mean annual values. These have been calculated as the simple mean or average $(\mu)$. Another important 
statistical function defining the spread or the variability of a dataset is the standard deviation $(\sigma)$ which is the square root of the variance. Degree of variation between datasets is defined by the coefficient of variation ( $(\varepsilon)$ which is also called the relative standard deviation. Further, as there is an inherent variation between different datasets, a method for standardization or normalization is required when studying the climate of a region with different datasets. A standardized anomaly

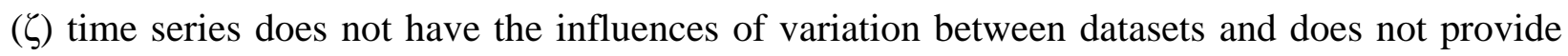
clearer information of the magnitude of the variation. Such time series has individual deviations within a time series that are divided by the standard deviation. Mean of such a standardized anomaly time series is 0 ; and 1 standard deviation is 1 itself. The formulas of the statistical functions used in the study are listed below:

$$
\begin{array}{lc}
\mu=\frac{\sum_{i=1}^{n} x_{i}}{n} & \sigma=\sqrt{\frac{\sum_{i=1}^{n}\left(x_{i}-\mu\right)^{2}}{n}} \\
\varepsilon=\frac{\sigma}{\mu} & \zeta=\frac{x_{i}-\mu}{\sigma}
\end{array}
$$

where:

$\mathrm{x}_{\mathrm{i}}=$ observed value

$\mu=$ simple mean/average of the dataset

$\varepsilon=$ coefficient of variation

$$
\begin{aligned}
& \mathrm{n}=\text { number of values in a dataset } \\
& \sigma=\text { standard deviation } \\
& \zeta=\text { standardized anomaly }
\end{aligned}
$$

Further, for the analysis of trends within the datasets, a non-parametric statistical test, the Mann-Kendall trend test (Mann, 1945; Kendall, 1975) has been used. This test detects the significant trends in the time series by analyzing the correlation between ranks within dataset values and the time series. This test is a two sided test and is sensitive to the null hypothesis that there is no significant trend within data series. If the null hypothesis is rejected then there is an 
indication of significant trend within the time series which may be positive or negative, as described by its score. This test is not dependant on the distribution of the dataset and does not vary with the outliers. Due to this reason, Mann-Kendall test is more suitable for detecting trends in the sporadic datasets currently available over Leh, which might have skewed distributions and may contain outliers. This test has been used to analyze if there are any significant trends in the temperature and precipitation datasets, to understand if the climatic patterns over the region are showing any significant changes at annual and/or seasonal scale. It is also used to analyze the changes in the number of days with higher precipitation.

Using this test three values for each data series is calculated; Kendall Tau, Kendall Score and its significance value (P-value) under null hypothesis. If the P-value is high, then the null hypothesis is accepted, and there is no discernible trend within the time series. But if the P-value is low, then the null hypothesis is rejected and there is a trend within the time series. With Pvalue falling under 0.05 , there is a significant trend indicated within the time series which is stated with 5\% significance level. Further, Kendall Tau and Kendall Score provide the test statistics for the analysis which describes the increase against time versus the decrease in the overall possible time-differences. Positive test statistics provide an indicator for increasing trend within the time series and negative test statistics indicate a decreasing trend for the dataset.

\section{Results and Discussion}

The main objective of the study is to understand the climate of the cold arid region of the Himalaya with a focus over the Ladhak region. Further, to find possibility of changing climate in terms of temperature and precipitation patterns. Specific attention also is given to the extreme events as these cause discernible impacts on the region, which might not always be the case in 
slowly changing climate. Thus, in the following sub-sections we discuss the climate and its extremes over the Ladhak region.

\subsection{Temperature}

Temperature variability of a region is the most important factor for its climatic studies. From daily temperature trends, it is observed that over Leh the temperature may vary from $34.8^{\circ} \mathrm{C}$ in summers and can drop to as low as $-27.9^{\circ} \mathrm{C}$ in the winters. But annual average daily temperature is around $+7.3^{\circ} \mathrm{C}$. Thus, as discussed before, Leh can be characterized as a cold region. Four different datasets from CRU, NNRP, ERA and IMDST were used to extract the monthly temperature over Leh. Fig. 1a shows the monthly averaged temperature over the years of data availability. This figure shows the general climate of the Leh region, with the summers (JAS) having higher temperatures and lowering of temperatures during winters (DJFM). But as noted in the figure, these observational datasets have inherent variability among themselves. The NNRP and ERA datasets have comparable observations but CRU and IMDST observations show a consistent positive deviation from the other two datasets by $5-7^{\circ} \mathrm{C}$ and $\sim 15^{\circ} \mathrm{C}$ respectively. To further understand this problem, correlation analysis is performed between the four datasets for the common time period of data availability (Table 2a). It is seen that all the four observational datasets show a very good correlation ( $>0.9$ ) between each other. So despite CRU and IMDST showing higher temperatures than the other two datasets, as seen in Fig. 1a, it is seen that this deviation from the other datasets is consistent. Thus, though each dataset may not provide an exact magnitude of the temperature variability, but the overall temperature pattern is captured accurately. This difference in these respective temperature fields could be attributed to the facts that what initial data framework is used for generating the final analysis and, secondly, difference in the analysis methods. 
Due to the inherent variability between the different datasets, a direct comparison among them would be inaccurate. Hence, the standardized anomaly is used to normalize the time series. Fig. $1 \mathrm{~b}$ shows the mean annual temperature anomaly for the dataset time series period of data availability with their linear trend line analysis. Overall, the trend analysis of all the three time series shows an increasing temperature trend (significant in case of CRU and ERA, but not for NNRP) over Leh showing a warming climate over the region except in the case of IMDST which shows no significant trend (IMD data is not available after 1991). A similar analysis is done for the four datasets for the whole period of data availability of each dataset as listed in Table 1 (supplementary Fig. S2). In that case also an increasing trend is observed for the temperature time series as the years progress. But in case of NNRP and IMDST datasets, the results of the trend are not significant. But overall a warming trend is observed over Leh over the years.

The annual temperature anomaly shows severe variability between the years but is consistent between the four time series (Fig. 1b). Apart from the overall warming trend over Leh, as seen from the linear trend lines from Fig. S2, to understand the variability between different years annual temperature anomaly is analyzed with each datasets' polynomial trend analysis (Fig. 2). When all the trend lines of different datasets are compared, similarities in the variability of temperature climatology appear. From a visual analysis it can be said that higher temperature was observed over Leh before 1979 as seen by the concave curve of the polynomial trend lines. Thus, from the time period 1901-1979 there is slight increasing trend of temperature over the years. After this long period, temperature shows a decreasing trend during the time period of 1979-1991, as seen by the convex curving of the trend line. After the short time period of cooling, the temperature again increases rapidly from 1991-2013. Thus, the current two decades show a significant and steep increase in the temperature over Leh, possibly foreshadowing 
further warming of the environment over the region. This warming in the recent years will have significant impact on the climate of the region. To understand if this pattern of warming, cooling and then warming again over different time periods is significant the Mann Kendall test is employed and described in the next paragraph. Similarly, seasonal analysis for winters, premonsoon, monsoon and post-monsoon (Fig. S3-S6) shows mostly warming trends in most of the datasets except in IMDST dataset. These unusual trends might be due to the short time extent of data availability.

To further analyze the significance of trends within time series Mann-Kendall statistical test has been used for the annual (for the whole time period 1901-2013) and seasonal (DJFM, AMJ, JJA, ON) temperature time series of the four datasets (Table 3a). Positive values of Kendall Score and Kendall Tau indicate increasing trends for temperature over time in both ERA and CRU datasets annually as well as in all seasons which is supported by P-value as well. Also, NNRP dataset shows a significant rising temperature in the winter season but lowering temperature during monsoons. There is no significant discernible trend within IMDST data series, which as mentioned before is possibly due to low number of observation points. Thus, the analysis shows a significant warning/rising temperatures over the Leh region in all seasons over the years (1901-2013), which might continue in the following years. But the periodic shift from warming to cooling to warming as indicated in the polynomial trend needs to be established. For this, the whole time period (1901-2013) has been divided in the three zones that have been described in Fig. 2 (1901-1978, 1979-1991 and 1992-2013). Mann Kendall test results for all the datasets for these three different time periods using monthly time series (providing large number of data points) has been shown in Table 3c. Some of the sections have been left blank as that particular dataset is not available for that time period. The period 1901-1978 shows an indication 
of significant increasing trend with CRU. Consequently, there is a significant cooling period afterwards from 1979-1991 as per IMDST. Again significant warming trend is noted with NNRP dataset in recent years from 1992-2013. Similar changes in temperature patterns were also indicated in the polynomial trend lines (Fig. 2). This continuous significant warming, cooling and again warming temperature changes define a definite pattern that might be influencing the climate of Leh.

For a temperature analysis for over the Ladakh region, IMD and Indian Air Force meteorological station datasets for five different locations in the district are considered (Leh, Base, Base Camp, Khalsi and Kargil). The time series calculated and available for these locations are the maximum and minimum temperature (Tmax and Tmin) as the annual average pentad temperature. Pentad temperature is the consecutive five days average of temperature over a year. Supplementary Fig. S3a represents the annual average pentad temperature in a graphical format. From the figure it is clear that the climate pattern over the Ladakh region is represented with warmer summer and colder winter temperature. Khalsi city shows higher temperatures as compared to other locations with Base Camp showing the lowest temperature in both maximum and minimum temperature trends. Figs. S7b and S7c show the coefficient of variation for minimum and maximum temperature respectively. Coefficient of variation describes the proclivity of variability within the observations. According to Fig. S7b we note two regions of spikes for minimum pentad temperature for April and October. Whereas for the maximum pentad temperature the variability is highest during December, January and February. This shows that maximum temperature over the Ladakh region fluctuates significantly during winter when the minimum temperature trend remains constantly low. And the minimum temperature fluctuates during pre-monsoon (spring) and post-monsoon (autumn) seasons. During the summer 
period the minimum and maximum temperatures show the least variability and remain consistent.

\subsection{Precipitation}

The next important variable discussed to understand the climate of the Ladakh region (Leh is considered as a representative) is precipitation. Precipitation patterns over Leh are studied using two station datasets (AIRFORCE and IMDS) and six gridded datasets (Table 1). The AIRFORCE, GPCC and GPCP have monthly precipitation time series whereas IMDG, APHRO, IMDS and TRMM have daily precipitation trends. Commensurating with the arid region response, calculated average daily precipitation for the three datasets shows very low precipitation over Leh. IMDS data shows $\sim 0.2 \mathrm{~mm} /$ day; APHRO and TRMM data show $\sim 0.5 \mathrm{~mm} /$ day and IMDG shows $\sim 1.5 \mathrm{~mm}$ /day of precipitation at Leh. Further, average annual

precipitation over Leh is $\sim 60 \mathrm{~mm} /$ year (IMDS), $\sim 150 \mathrm{~mm} /$ year (APHRO), $\sim 200 \mathrm{~mm} /$ year (TRMM) and $\sim 300 \mathrm{~mm} /$ year (IMDG) respectively.. Despite the inherent variations among the datasets, it can be said that the precipitation is minimal over Leh region making it dry and arid. However, recent studies have shown significantly higher precipitation along the ridges of Ladakh range (Thayyen, 2016, ref: DST Report). Due to the inherent variation between the different observations a correlation analysis is done. The correlation analysis for different precipitation datasets (Table 2b) shows positive correlation among all datasets but the correlation coefficients are low. Only CMORPH and IMDG show negative correlation. Whereas CMORPH and TRMM have no correlation with IMDS dataset due to lack of common data points in the time series. AIRFORCE and IMDS station datasets show the highest correlation ( $>0.9)$ between each other. APHRO dataset shows some significant correlation to GPCP, IMDG and GPCC. Further, GPCP also shows higher correlation to GPCC and TRMM. And IMDG and GPCC also show higher 
correlation between them. But rest of the datasets show poor correlations. Thus, it is imperative that any analysis over Leh using these datasets must be normalized and must be in form of the standardized anomaly time series.

Fig. 3a shows the annual trend of monthly precipitation anomaly. This represents the generalized precipitation patterns over Leh. Fig. 3b shows the annual 11day average precipitation anomaly for the five datasets having daily precipitation available. Similar analysis of the annual average daily precipitation anomaly and their respective 5day average is also considered (supplementary Fig. S8). The 11day or 5day average smoothens the highly variable curve of daily precipitation trends. From the figures (Fig. 3a, 3b and supplementary Fig. S8) it can be noted that, as over most of the Indian sub-continent, Leh has maximum precipitation during the monsoon period (JAS). High precipitation is not seen during June as monsoon trough travels over the Indian sub-continent to reach the northern most part of India by July. In post-monsoon period $(\mathrm{ON})$, the retreat of north-east monsoon shows very little precipitation over Leh. But the winters and pre-monsoon periods show some precipitation (DJFM). These precipitation events are related to the western disturbances (Dimri and Chevuturi, 2014; Dimri et al. 2015) which brings precipitation over northern India during winter. Further, some strong western disturbances may also impact the region during pre-monsoon period. Though low correlation is seen between the datasets (Table 2b), as seen from the Fig. 3a, overall there seems to be relative correlation between the datasets. But the IMDG and CMORPH datasets show higher deviation for precipitation anomaly than the other datasets. Whereas from other two figures (Fig. 3b and supplementary Fig. S8), it is seen that IMDG shows high peaks during March and December and CMORPH shows during monsoon and November but very low precipitation during December and January, whereas TRMM datasets shows peak during monsoon and February. 
For an analysis of the climatology of precipitation trends, annual precipitation anomalies of all the eight precipitation observation datasets are plotted along with their trend lines (Fig. 4, supplementary Fig. S5). When all the datasets are analyzed individually (supplementary Fig. S9), it is observed that all datasets show varying precipitation trends. AIRFORCE, TRMM and GPCP datasets show decreasing trend of precipitation over the years with low significance as seen in AIRFORCE dataset. Whereas, IMDG, APHRO, CMORPH, IMDS and GPCC show increasing precipitation trends, but IMDG, APHRO and IMDS show very low increase. Due to the datasets showing varing overall linear precipitation trends over Leh, further analysis is done using polynomial trend lines (Fig. 4). As the datasets are available for variable periods with some of the time period of availability of data being very small all the datasets are analyzed against the whole time line of data availability (1901 to 2013) in the Fig. 4. Though in this alternate method of analysis each datasets trend analysis is limited to the time period of that data availability. This comparative analysis comes up with interesting information on precipitation climatology over Leh. With different precipitation observations having low correlation some generalizations and extrapolations have to be made in the interpretation of results. From the figure it can be seen though annual precipitation anomalies show variation, the trend lines show similarities and correlation in the patterns. From a visual analysis it can be said that lower precipitation trend was observed over Leh before 1970 as seen by the convex curve of the polynomial trend lines. Whereas, after 1970 and till 1995 precipitation shows an increasing trend. Though the peaks of each dataset vary, it can be said that during the time period of 1970-1995 there is increasing trend of precipitation. Though it cannot be said this annually increasing trend is due to increase in high amounts of daily precipitation or due to increase in the extreme precipitating events over the region. After 1995 to 2012 there is again a decreasing trend of annual precipitation anomaly. 
This variable precipitation pattern over the last century have been also analyzed statistically using Mann Kendall test which is described later in this section. Further, during the period of low precipitation which may be due to low precipitation amounts but still has increasing trends of extreme events. This will be further discussed in the following paragraph. Overall Leh has shown low precipitation before 1970, which increased subsequently during the period of 1970-1995 and the precipitation trend shows a decline after 1995.

Even seasonwise precipitation analysis (Fig. S10-14) shows varied linear trends or no trends in data series. In winter season, GPCP and AIRFORCE dataset shows reducing precipitation over the years whereas IMDG, IMDS and GPCC shows slightly increasing precipitation. During monsoon, IMDG, CMORPH and GPCC shows increase in precipitation whereas AIRFORCE, TRMM and GPCP shows reduction in precipitation. This varied increasing or decreasing precipitation in different datasets do not give a clear picture as to what is the actual indication of change in precipitation patterns over the region. Mann Kendall non-parametric test over all the eight datasets (Table 3b) also provides varied patterns of change over Leh. Annually CMORPH and GPCC suggests significantly increasing precipitation, where as GPCP shows a reducing trend. Both monsoon and post-monsoon season shows significantly increasing precipitation with GPCC and CMORPH. In fact annually as well as seasonally, CMORPH (one of the smallest time extent dataset) and GPCC (one of the largest time extent dataset) shows significantly increasing precipitation over Leh. During winters AIRFORCE and in pre-monsoons GPCP shows significantly decreasing precipitation over the years. So over the years there is a possible increasing precipitation pattern as per most of the datasets even though polynomial trend line suggests decreasing trend in the current time period. It also showed a time of increasing precipitation in recent past which might describe the overall reducing precipitation. 
Thus changing precipitation patterns over different time periods is a must to understand if the indication provided by the polynomial trends is correct or not. Similar to the temperature analysis over different time periods (Table 3c), for precipitation also the whole time extent (1901-2013) has been divided into three sections (1901-1969, 1970-1995 and 1996-2013) as described in Fig. 4. Over these three time sections, Mann Kendall test is applied on the available data time series (Table 3d). The analysis for the first time section (1901-1969) with both available dataset APHRO and GPCC shows a consistent significant reducing trend in precipitation with both datasets. When considering the next time period (1970-1995), there is significant increasing precipitation patterns with APHRO, IMDG, GPCC and IMDS datasets. And in the most recent time period (1996-2013) again there is a significant reducing trend in precipitation with GPCP and IMDG. This analysis consistent with the polynomial trend analysis again provides an insight to a changing regime of precipitation patterns over the last century. This changing regime goes from decreasing to increasing to again decreasing patterns of precipitation even if there is an overall increase in precipitation patterns over time.

The increase of annual precipitation as discussed before can be due to the increase in precipitation amounts over the whole year or low precipitation interspersed with some extreme precipitating events. On the other hand decrease in annual precipitation can be due to reduced precipitation amounts over this arid region but still have increasing extreme events. Thus, it is imperative to understand the increase in the extreme events in precipitation to understand how the climatology of the region is changing, instead of just the average trend. Higher precipitating events though are not studied individually due to lack of storm data. Extreme in daily precipitations can be a good representative of precipitation extremes. In Fig. S14a time series of number of days greater than +1 standard deviation $(+1 S D)$ is represented. Here it can be seen 
that some years may either show higher number of days or lower number of days with precipitation greater than +1 standard deviation of each year respectively. In all the five time series there is a slight increasing/decreasing trend of number of days with high precipitation. But further statistical analysis of the data series with Mann Kendall test (Table 3e) shows that though again all datasets show varied increasing or decreasing trends but only IMDS and TRMM show statistically significant reducing number of days of precipitation exceeding $+1 \mathrm{SD}$ at $5 \%$ significance level (P-value less than 0.05). Given the very short duration of cloudburst events (Thayyen et al., 2013), assessment of the impact of the extreme events through the constructed climate data is a huge challenge. Hence we can only expect such subdued indications in this data. But there seems to be a rise in the reports of heavy precipitation events over the region in recent times. These increasing reporting in the region could also be due to increased tourism, population and communication in the recent decade. If considering the time series for number of days with precipitation beyond +2 standard deviation ( $+2 \mathrm{SD}$ ), we note that there is no significant increase or decrease in the trend (Fig. S6b). No significant trend is seen in the number of days with precipitation higher than $+2 \mathrm{SD}$ at $5 \%$ significance but if $10 \%$ significance is considered (Pvalues less than 0.1) TRMM shows a statistically significant decreasing trend. From the current study no concrete proof can be provided to suggest the decrease in the extreme events only that there might be indication of days with high precipitation might be reducing. This reduction might be due to overall precipitation reduction or reducing extreme events. These extreme events which occur for a short period of time might not be reflected through the current datasets. Thus, detailed further analysis with longer hourly datasets is imperative.

\section{Summary and Conclusions}


Ladakh region in the south of the Karakorum Range is unique with its cold-arid climate and vast barren landscape. People in this region sustain on scarce natural resources and small changes in climate of the region could bring hardship to the people. However, characteristics of the changing climate are not well understood due to the limited monitoring facilities operated in this region. Hence, present study focused on understanding the general climate of the region and its changes during the past decades.

Leh at $3500 \mathrm{~m}$ a.s.l. shows extreme annual range of temperature ranging between $34.8^{\circ} \mathrm{C}$ in summer to $-27.9^{\circ} \mathrm{C}$ in winter with an annual mean temperature of $7.3^{\circ} \mathrm{C}$. The precipitation over Leh falls mostly during the monsoon period with the extreme precipitating events (cloudbursts) also occurring during the same period. During winter and pre-monsoon also there is significant precipitation over Leh due to the influence of western disturbances. But on an average the daily precipitation amounts range between $0.5-1.5 \mathrm{~mm} /$ day. These conditions define the climate of Leh region as a cold and arid (dry).

The changing climate shows a slowly changing trend of the climate variables when considered as a time series. A statistical analysis of the climate over Leh using different datasets shows a slight but significant trend of change. Considering the different temperature datasets over Leh, there is an overall significant warming trend over the years in most datasets. On the other hand, overall linear precipitation trends over Leh show varied results with different datasets, with some showing increasing and others showing decreasing trends, but significant increasing precipitation is seen in few datasets. Further analysis of temperature and precipitation variability of Leh climatology is analyzed using polynomial trend lines with a comparative analysis between different datasets. This comparative analysis comes up with interesting information on the climatology over Leh. It is noted that from 1901-1979 is warm period over 
Leh followed by lowering temperature during 1979-1991, after which from 1991 onwards, the temperature again increased rapidly. Further, analysis of precipitation reveals that, after a low precipitation period before 1970, there was a period of increasing precipitation trend from 19701995, but after 1995 onwards there is again a decreasing trend in the precipitation. This varied trend of increasing/decreasing temperature and precipitation over different time periods is statistically significant. Further, the variable temperature and precipitation trends show that there is somewhat of an inverse relationship between temperature and precipitation over Leh. Before 1970s, there was a relative warm period which led to lower precipitation over the region. Between 1970s to mid 1990s there is higher precipitation over Leh associated with lowerd temperature. In the recent decades, mid 1990s onwards, the temperature is showing a rapid increasing trend and consequently precipitation shows a decreasing trend. Despite the decreasing trend of precipitation amounts over the region in recent decades, there is an overall increasing trend of precipitation and warming temperatures over the years for Leh. There is also some indication of decreasing number of days having high precipitation though reported otherwise. This suggests that overall the region is receiving more rainfall than the arid region is used to.

This analysis indicating rapid increase in temperature and varied precipitation patterns in recent decades foreshadows further changing climate with higher probability of unexpected events over the Leh region in the coming years. This change in the climatic pattern might have irreversible impacts over the region leading to devastating consequences. Any region which is adapted to its climate consistent over many years; changing climate is problematic as it disrupts the delicate balance between the historical climate and ecology of the region. Though Leh is a cold and arid region, a warming environment and shift in precipitation patterns will have a significant impact on the ecology, vegetation, wildlife, hydrology, cryosphere and even the 
human society (agriculture and transport). Increasing precipitation might be considered good for an arid region from an anthropogenic point of view but will not be correct at all for the region's ecosystem. In addition, this increase in form of extreme events or cloudbursts further cause extreme amount of devastation without the possibility of water excess available during the time to be stored for future. Thus, changing climate over the region will significantly impact the region negatively and perhaps irrevocably.

Limitations in detailed studies over the region are due to the sparse network of stations providing current data and lack of records of detailed historic data. This causes not only gaps in dataset but also inherent variation between even the observational datasets. Further questions that urgently need to be answered are the impacts of warming conditions over Leh, tele-connections between the warming temperature trend and precipitation trends/extreme events and local forcings of cloudburst events. And such questions need to be studied in the light of proof of changing climate over Leh. Due to the imminent change in the climatic patterns these detailed climatic studies over the region can form a basis for strong climate change adaptation policies.

\section{Acknowledgements}

Authors thank Dr. (AVM) A. Tyagi for providing various station data in the different stations in the Ladakh region. Authors acknowledge the use of different gridded datasets that have been detailed in the chapter with in text citations and references.

\section{References}

Adler RF, Huffman GJ, Chang A, Ferraro R, Xie P, Janowiak J, Rudolf B, Schneider U, Curtis S, Bolvin D, Gruber A, Susskind J, Arkin P (2003) The Version 2 Global Precipitation Climatology Project (GPCP) Monthly Precipitation Analysis (1979-Present). J Hydrometeorol, 4: 1147-1167. 
Archer DR, Fowler HJ (2004) Spatial and temporal variations in precipitation in the Upper Indus Basin, global teleconnections and hydrological implications. Hydrol Earth Syst Sci, 8(1): 47-61.

Bhutiyani MR, Kale VS, Pawar NJ (2007) Long-term trends in maximum, minimum and mean annual air temperatures across the Northwestern Himalaya during the twentieth century. Clim Chang, 85(1-2): 159-177.

Bhutiyani MR, VS Kale, NJ Pawar (2010) Climate change and the precipitation variations in the northwestern Himalaya: 1866-2006. Int J Climatol, 30: 535-548.

Bookhagen B, Burbank DW (2010) Toward a complete Himalayan hydrological budget: Spatiotemporal distribution of snowmelt and rainfall and their impact on river discharge. J Geophys Res: Earth Surface (2003-2012), 115(F3)

Chevuturi A, Dimri AP, Das S, Kumar A, Niyogi D (2015) Numerical simulation of an intense precipitation event over Rudraprayag in the central Himalayas during 13-14 September 2012. J Earth Syst Sci, 124(7): 1545-1561.

Das S, Ashrit R, Moncrieff MW (2006) Simulation of a Himalayan cloudburst event. J Earth Syst Sci, 115(3): 299-313.

Dash SK, Jenamani RK, Kalsi SR, Panda SK (2007) Some evidence of climate change in twentieth-century India. Clim Chang, 85(3-4): 299-321.

Dee DP, Uppala SM, Simmons AJ, Berrisford P, Poli P, Kobayashi S, Andrae U, Balmaseda MA, Balsamo G, Bauer P, Bechtold P, Beljaars ACM, van de Berg L, Bidlot J, Bormann N, Delsol C, Dragani R, Fuentes M, Geer AJ, Haimberger L, Healy SB, Hersbach H, H’olm EV, Isaksen L, Kallberg P, Kohler M, Matricardi M, McNally AP, Monge-Sanz BM, Morcrette JJ, Park BK, Peubey C, de Rosnay P, Tavolato C, Th'epaut JN, Vitart F 
(2011) The ERA-Interim reanalysis: Configuration and performance of the data assimilation system. Quart J Royal Meteorol Soc, 137: 553-597.

Dey B, Bhanu Kumar OSRU (1982) An apparent relationship between Eurasian spring snow cover and the advance period of the Indian summer monsoon. J Appl Meteorol, 21(12): 1929-1932.

Dimri AP, Chevuturi A (2014) Model sensitivity analysis study for western disturbances over the Himalayas. Meteorol Atmos Phys, 123: 155-180.

Dimri AP, Dash SK (2012) Wintertime climatic trends in the western Himalayas. Clim Chang, 111(3-4): 775-800.

Huffman GJ, Adler RF, Bolvin DT, Gu G, Nelkin EJ, Bowman KP, Hong Y, Stocker EF, Wolff DB (2007) The TRMM Multi-satellite Precipitation Analysis: Quasi-Global, Multi-Year, Combined-Sensor Precipitation Estimates at Fine Scale. J Hydrometeorol, 8(1): 38-55.

Immerzeel WW, Pellicciotti F, Bierkens MFP (2013) Rising river flows throughout the twenty first century in two Himalayan glacierized watersheds. Nat. Geosci., 6: 742-745.

Immerzeel WW, Van Beek LPH, Bierkens MFP (2010) Climate Change will affect the Asian Water Towers. Sci, 328: 1382-1385.

IPCC, 2013: Climate Change 2013: The Physical Science Basis. Contribution of Working Group I to the Fifth Assessment Report of the Intergovernmental Panel on Climate Change [Stocker, T.F., D. Qin, G.-K. Plattner, M. Tignor, S.K. Allen, J. Boschung, A. Nauels, Y. Xia, V. Bex and P.M. Midgley (eds.)]. Cambridge University Press, Cambridge, United Kingdom and New York, NY, USA, 1535 pp, doi:10.1017/CBO9781107415324.

Jhajharia D, Singh VP (2011) Trends in temperature, diurnal temperature range and sunshine duration in Northeast India. Int J Climatol, 31: 1353-1367. doi: 10.1002/joc.2164 
Joyce RJ, Janowiak JE, Arkin PA, and Xie P (2004) CMORPH: A method that produces global precipitation estimates from passive microwave and infrared data at high spatial and temporal resolution. J Hydrometeorol, 5: 487-503.

Kalnay E, Kanamitsu M, Kistler R, Collins W, Deaven D, Gandin L, Iredell M, Saha S, White G, Woollen J, Zhu Y, Leetmaa A, Reynolds R, Chelliah M, Ebisuzaki W, Higgins W, Janowiak J, Mo KC, Ropelewski C, Wang C, Jenne R, Joseph D (1996) The NCEP/NCAR 40-Year Reanalysis Project. Bull Am Meteorol Soc, 77: 437-471.

Kaser G, Großhauser M, Marzeion B (2010) Contribution potential of glaciers to water availability in different climate regimes, P. Natl. Acad. Sci. USA, 107: 20223-20227, doi:10.1073/pnas.1008162107.

Kendall, M.G., 1975. Rank Correlation Methods. Griffin, London

Kumar KK, Rajagopalan B, Cane MA (1999) On the weakening relationship between the Indian monsoon and ENSO. Sci, 284(5423): 2156-2159.

Kumar MS, Shekhar MS, Krishna SR, Bhutiyani MR, Ganju A (2012) Numerical simulation of cloud burst event on August 05, 2010, over Leh using WRF mesoscale model. Nat Haz, 62(3): 1261-1271.

Le Masson V, Nair K (2012) Does climate modeling help when studying adaptation to environmental changes? the case of Ladakh, India. Climate Change Modeling For Local Adaptation In The Hindu Kush-Himalayan Region. Community, Environment and Disaster Risk Management, vol. 11. Emerald Group Publishing, 75-94.

Mann, H.B., 1945. Nonparametric tests against trend. Econometrica 13, 245-259.

Nandargi S, Dhar ON (2011) Extreme rainfall events over the Himalayas between 1871 and 2007. Hydrol Sci J, 56(6): 930-945. 
New M, Lister D, Hulme M, Makin I (2002) A high-resolution data set of surface climate over global land areas. Clim Res, 21(1): 1-25. doi:10.3354/cr021001.

Rajeevan M, Bhate J (2009) A high resolution daily gridded rainfall dataset (1971-2005) for mesoscale meteorological studies. Curr Sci, 96(4): 558-562.

Rienecker MM, Suarez MJ, Gelaro R, Todling R, Bacmeister J, Liu E, Bosilovich MG, Schubert SD, Takacs L, Kim GK, Bloom S, Chen J, Collins D, Conaty A, da Silva A, Gu W, Joiner J, Koster RD, Lucchesi R, Molod A, Owens T, Pawson S, Pegion P, Redder CR, Reichle R, Robertson FR, Ruddick AG, Sienkiewicz M, Woollen J (2011) MERRA: NASA's modern-era retrospective analysis for research and applications. J Clim, 24: 3624-3648.

Schneider U, Becker A, Finger P, Meyer-Christoffer A, Rudolf B, Ziese M (2011) GPCC Full Data Reanalysis Version 6.0 at $1.0^{\circ}$ : Monthly Land-Surface Precipitation from RainGauges built on GTS-based and Historic Data. doi:10.5676/DWD_GPCC/FD_M_V6_100.

Shekhar MS, Chand H, Kumar S, Srinivasan K, Ganju A (2010) Climate-change studies in the western Himalaya. Ann Glaciol, 51(54): 105-112.

Thayyen RJ, Dimri AP, Kumar P, Agnihotri G (2013) Study of cloudburst and flashfloods around Leh, India during August 4-6, 2010. Nat Haz, 65(3): 2175-2204.

UNEP (2009) Mountains as Early Indicators of Climate Change. Proceedings of the International Conference, 17-18 April 2008, Padova, Italy.

Yadav RK, Park WK, Singh J, Dubey B (2004) Do the western Himalayas defy global warming? Geophy Res Lett, 31: L17201. doi:10.1029/ 2004GL020201. 
Yadav RK, RupaKumar K, Rajeevan M (2010) Climate change scenarios for Northwest India winter season. Quat Int, 213(1-2): 12-19.

Yatagai A, Arakawa O, Kamiguchi K, Kawamoto H, Nodzu MI, Hamada A (2009) A 44-year daily gridded precipitation dataset for Asia based on a dense network of rain gauges. Sci Online Lett Atmos, 5: 137-140. 

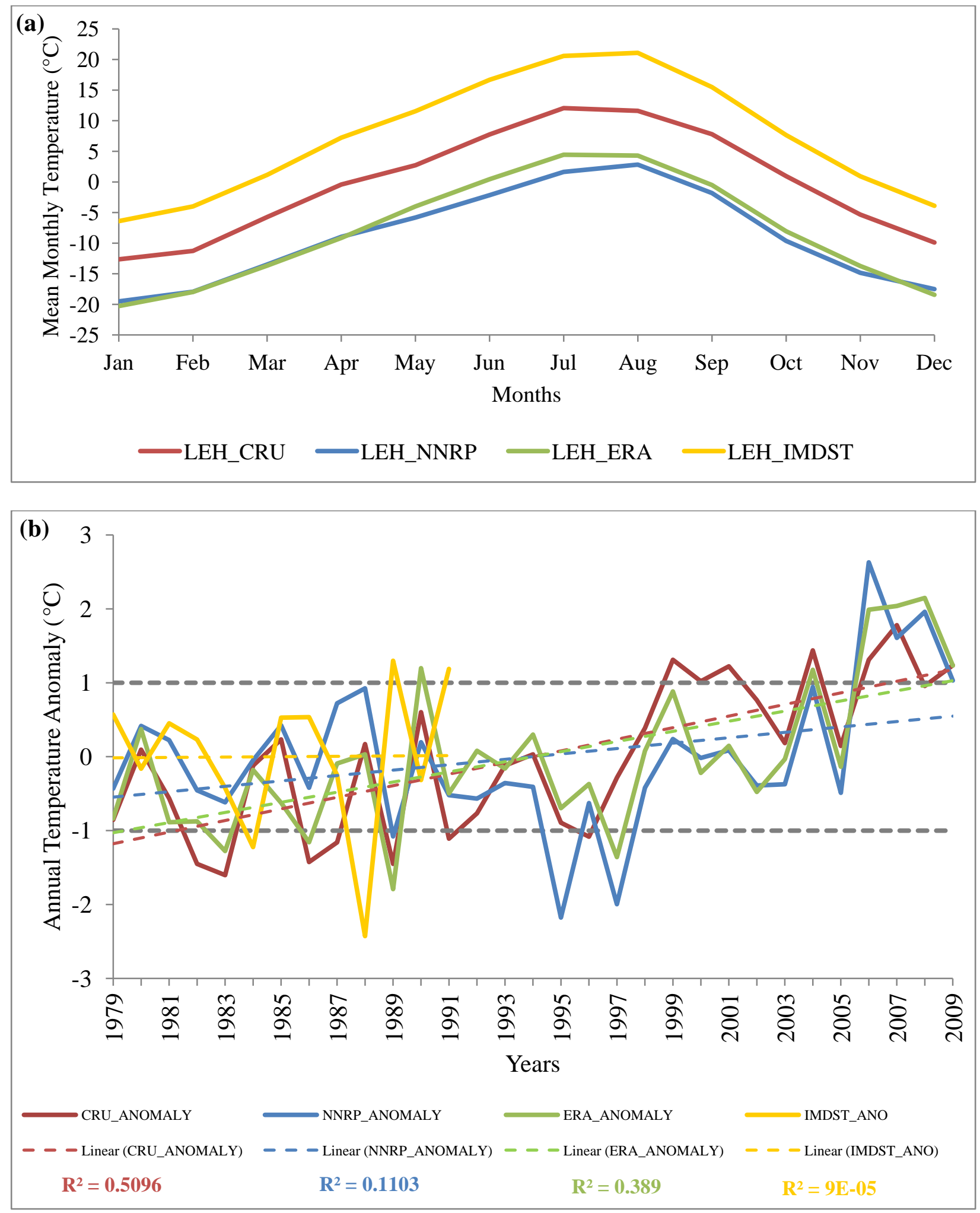

Fig. 1: (a) Mean monthly temperature $\left({ }^{\circ} \mathrm{C}\right)$ and (b) annual temperature anomaly $\left({ }^{\circ} \mathrm{C}\right.$; solid lines) and respective linear trend lines (dashed lines) over Leh for CRU (red), NNRP (blue), ERA (green) and IMDST (yellow) datasets from 1979-2009. 


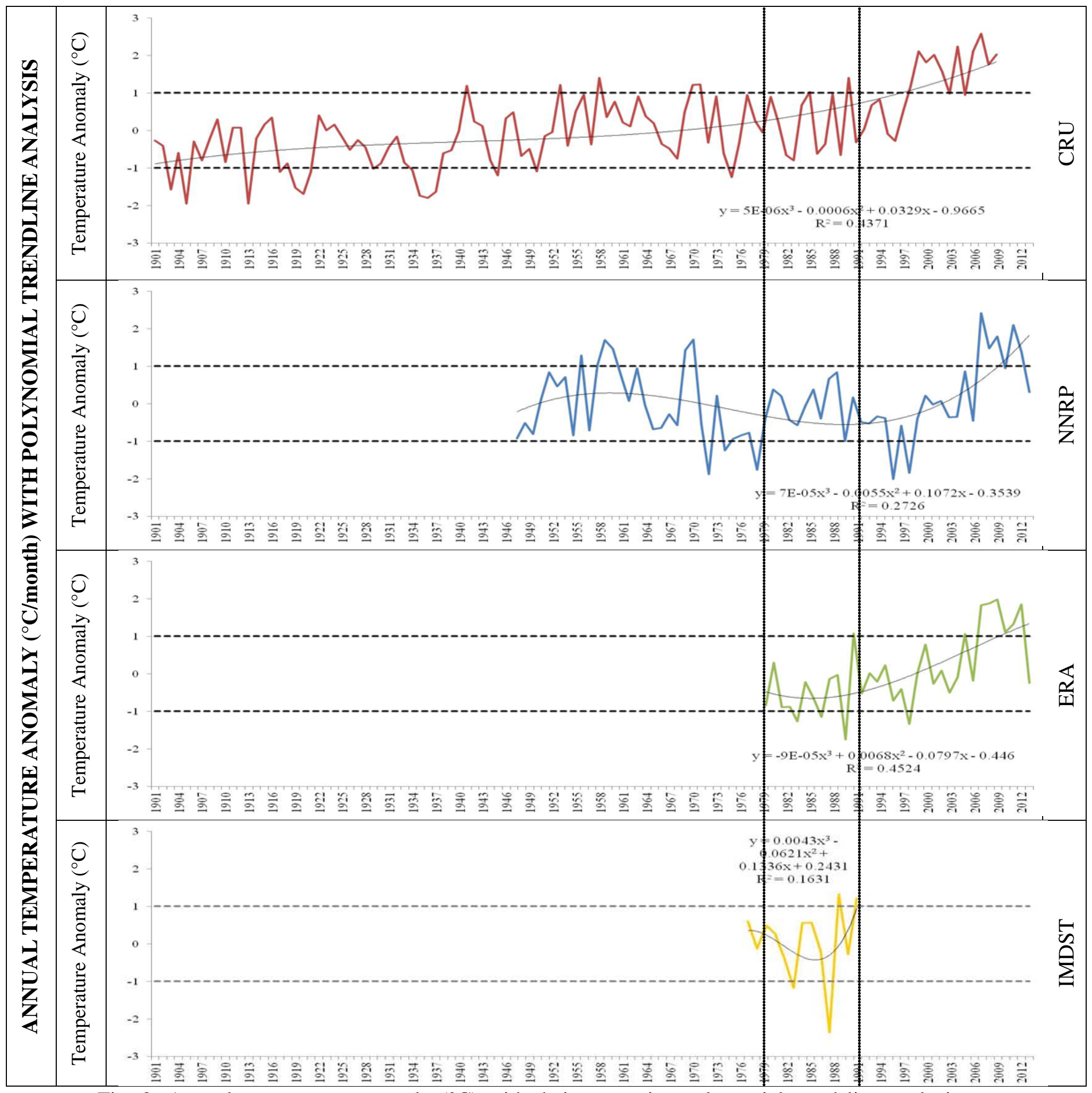

Fig. 2: Annual temperature anomaly $\left({ }^{\circ} \mathrm{C}\right)$ with their respective polynomial trend line analysis

(black solid lines) over Leh for CRU (red), NNRP (blue), ERA (green) and IMDST (yelllow).

Black dashed horizontal lines demarcate the +/- 1SD lines and black dotted vertical lines demarcate time period between 1979-1991. 

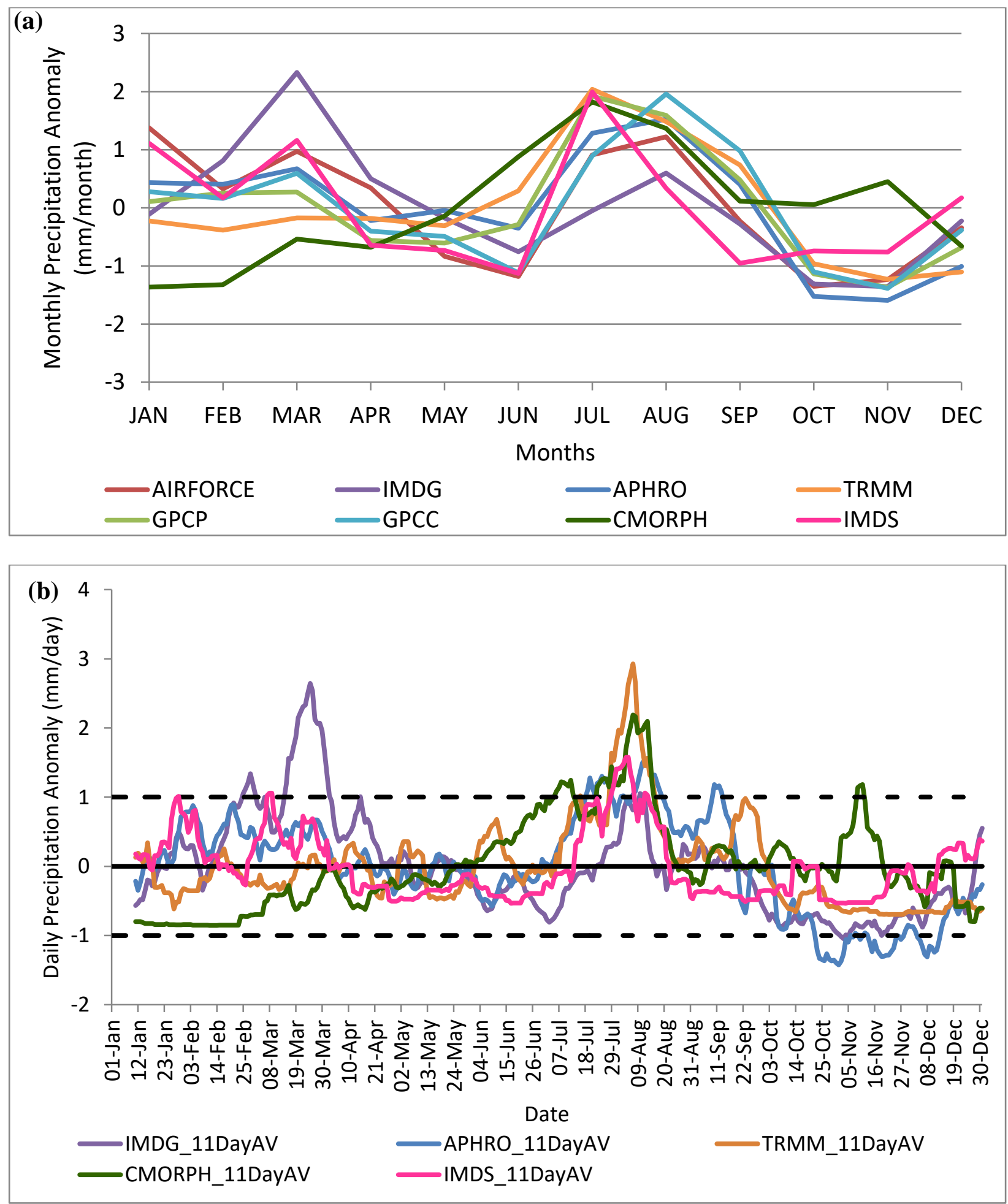

Fig. 3: (a) Annual average monthly precipitation anomaly (mm) and (b) annual average daily precipitation anomaly as a 11day average, over Leh for IMDG (purple), APHRO (blue), TRMM (orange), CMORPH (darkgreen) and IMDS (pink). 


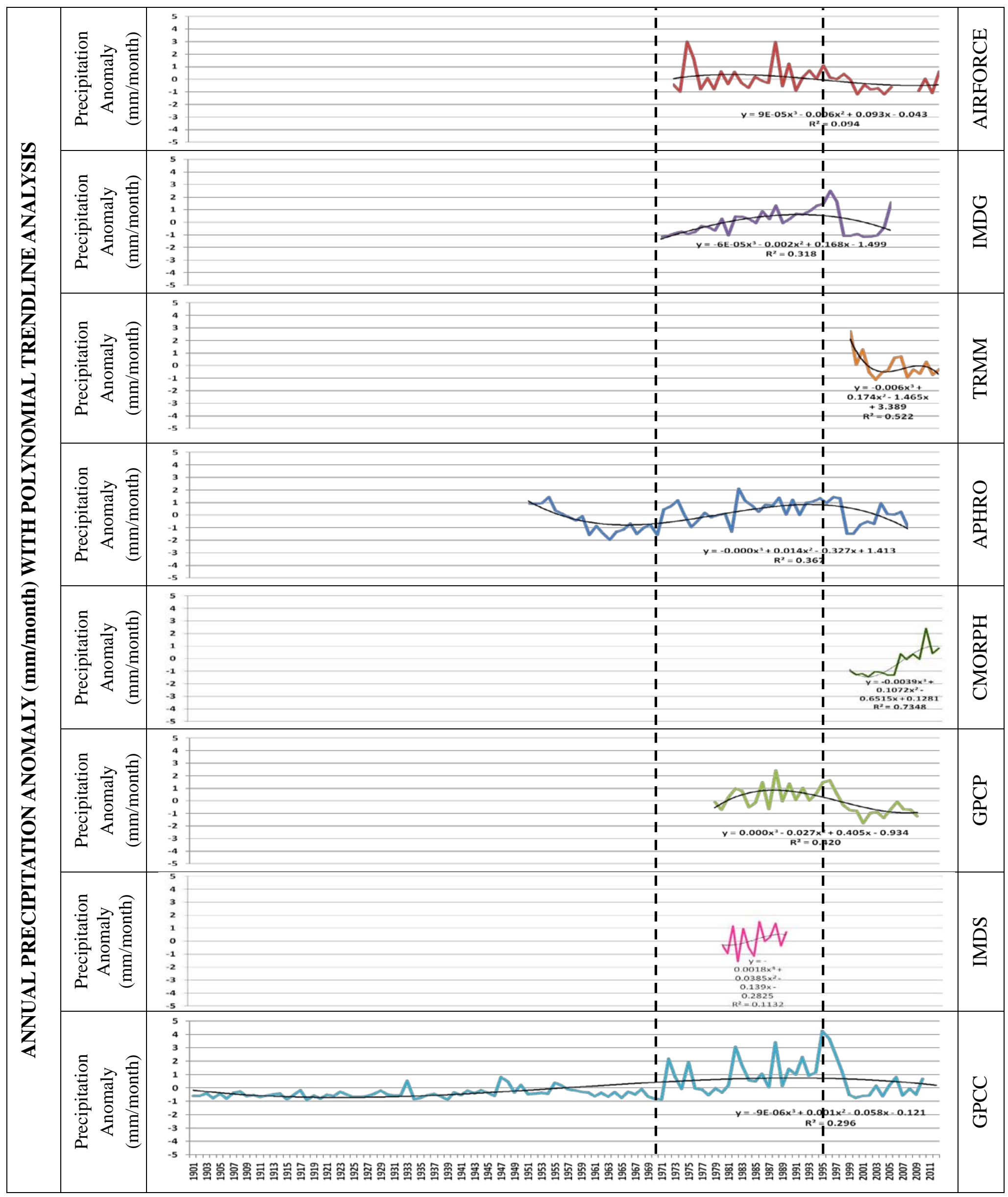


Fig. 4: Annual precipitation anomaly (mm/month) with their respective polynomial trend line analysis (black solid lines) over Leh for AIRFORCE (red), IMDG (purple), APHRO (blue), TRMM (orange), CMORPH (darkgreen), GPCP (lightgreen), IMDS (pink) and GPCC (cyan). Black dashed lines demarcate the time period between 1970-1995. 
Table 1: Datasets for Ladhakh region and Leh used in the study with the time period of availability for (a) temperature $\left({ }^{\circ} \mathrm{C}\right.$ ) and (b) precipitation (mm). Columns marked GD give information about the gridded datasets.

\begin{tabular}{|c|c|c|c|c|c|c|c|c|}
\hline & $\begin{array}{l}\text { DATASE } \\
\mathbf{T}\end{array}$ & $\begin{array}{l}\text { TIME } \\
\text { PERI } \\
\text { OD } \\
\text { OF } \\
\text { DATA } \\
\text { USED }\end{array}$ & $\begin{array}{l}\text { DATA } \\
\text { TYPE }\end{array}$ & $\begin{array}{l}\text { REFER } \\
\text { RED AS }\end{array}$ & $\begin{array}{l}\text { REFERENCE \& } \\
\text { SOURCE }\end{array}$ & DETAILS (GD) & $\begin{array}{c}\text { TIME PERIOD } \\
\text { (GD) }\end{array}$ & $\begin{array}{l}\text { SPATIAL } \\
\text { RESOLUTIO } \\
\quad \text { N (GD) }\end{array}$ \\
\hline \multirow{3}{*}{ 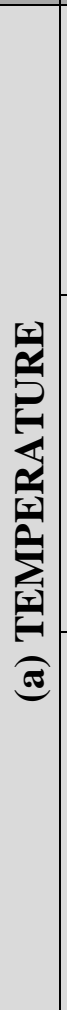 } & $\begin{array}{l}\text { CRU } \\
\text { (Climate } \\
\text { Research } \\
\text { Unit) } \\
\text { Reanalysis } \\
\text { over Leh }\end{array}$ & $\begin{array}{l}\text { Jan- } \\
1901 \\
\text { to } \\
\text { Dec- } \\
2009\end{array}$ & $\begin{array}{l}\text { Monthly } \\
\text { Tempera } \\
\text { ture }\left({ }^{\circ} \mathrm{C}\right)\end{array}$ & CRU & $\begin{array}{l}\text { Harris et al., } 2014 \\
\text { http://catalogue.ceda.ac.u } \\
\text { k/uuid/3f8944800cc48e1c } \\
\text { bc29a5ee12d8542d }\end{array}$ & $\begin{array}{c}\text { CRU (Climate } \\
\text { Research Unit) } \\
\text { Reanalysis Version } \\
3.10\end{array}$ & 1901-2009 & $0.5^{\circ} \times 0.5^{\circ}$ \\
\hline & $\begin{array}{l}\text { NNRP } \\
\text { (NCEP/NC } \\
\text { AR } \\
\text { Reanalysis } \\
\text { Project) } \\
\text { Data over } \\
\text { Leh }\end{array}$ & $\begin{array}{l}\text { Jan- } \\
1948 \\
\text { to } \\
\text { Dec- } \\
2012\end{array}$ & $\begin{array}{l}\text { Monthly } \\
\text { Tempera } \\
\text { ture }\left({ }^{\circ} \mathrm{C}\right)\end{array}$ & NNRP & $\begin{array}{c}\text { Kalnay et al., } 1996 \\
\text { http://users.ictp.it/ pubreg } \\
\text { cm/RegCM4/globedat.ht } \\
\text { m\#part3a }\end{array}$ & $\begin{array}{l}\text { Output of CDAS } \\
\text { global reanalysis } \\
\text { model }\end{array}$ & 1948 onwards & $2.5^{\circ} \times 2.5^{\circ}$ \\
\hline & $\begin{array}{l}\text { ERA - } \\
\text { Interim } \\
\text { (ECMWF } \\
\text { Interim } \\
\text { Reanalysis } \\
\text { Data } \\
\text { Archive) } \\
\text { over Leh }\end{array}$ & $\begin{array}{l}\text { Jan- } \\
1979 \\
\text { to } \\
\text { Dec- } \\
2012\end{array}$ & $\begin{array}{l}\text { Monthly } \\
\text { Tempera } \\
\text { ture }\left({ }^{\circ} \mathrm{C}\right)\end{array}$ & ERA & $\begin{array}{c}\text { Dee et al., } 2011 \\
\text { http://users.ictp.it/ pubreg } \\
\text { cm/RegCM4/globedat.ht } \\
\text { m\#part2a }\end{array}$ & $\begin{array}{l}\text { Reanalysis from } \\
\text { ECDAS with an } \\
\text { improved } \\
\text { atmospheric model } \\
\text { and assimilation } \\
\text { system over ERA-40 }\end{array}$ & 1979 onwards & $1.5^{\circ} \times 1.5^{\circ}$ \\
\hline
\end{tabular}




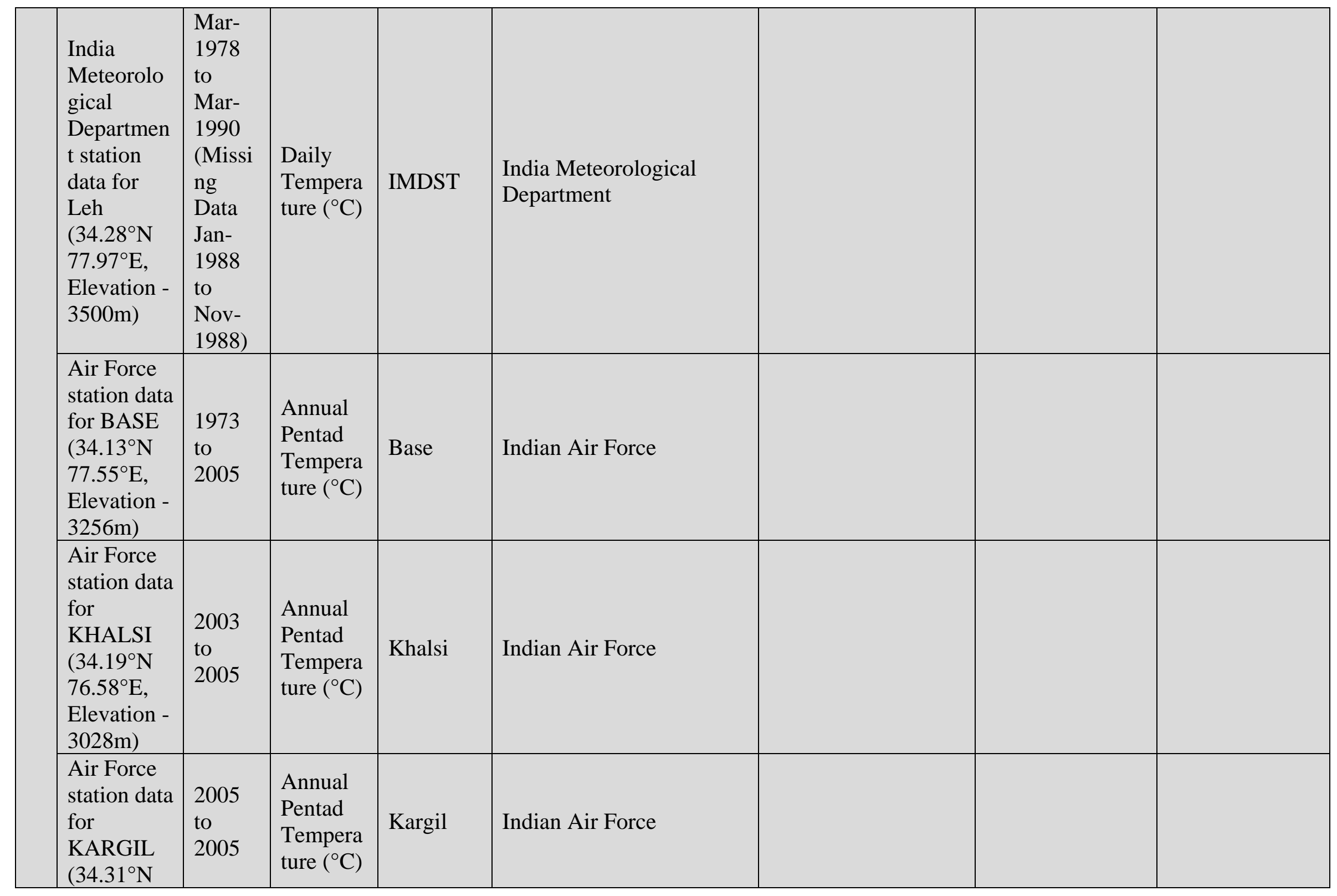




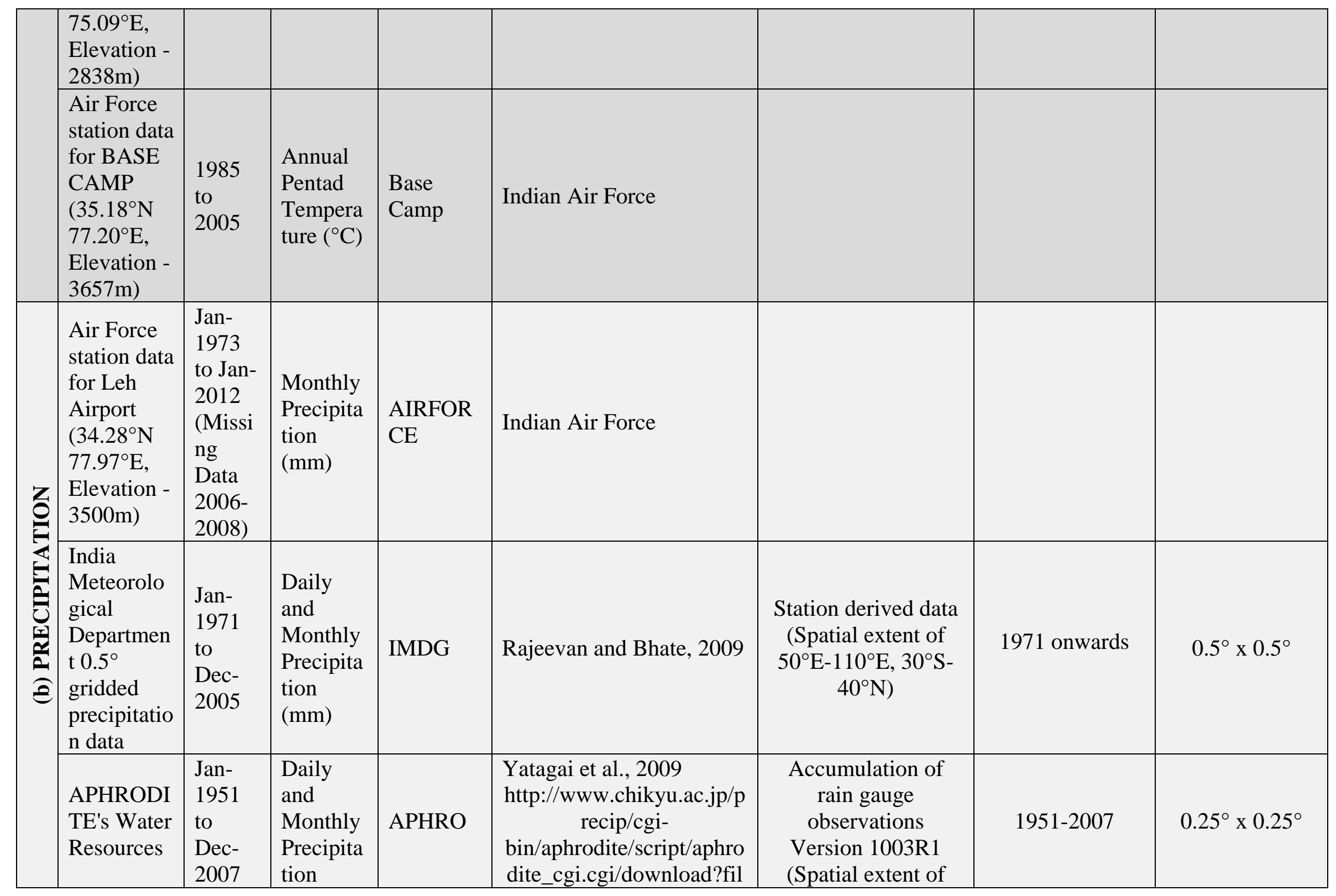




\begin{tabular}{|c|c|c|c|c|c|c|c|}
\hline & & $(\mathrm{mm})$ & & $\begin{array}{c}\mathrm{e}=\% 2 \mathrm{FV} 1003 \mathrm{R} 1 \% 2 \mathrm{FAP} \\
\text { HRO_MA_V1003R1\%2F } \\
\text { 025deg }\end{array}$ & $\begin{array}{c}60^{\circ} \mathrm{E}-150^{\circ} \mathrm{E}, 15^{\circ} \mathrm{S}- \\
\left.55^{\circ} \mathrm{N}\right)\end{array}$ & & \\
\hline $\begin{array}{l}\text { Tropical } \\
\text { Rainfall } \\
\text { Measuring } \\
\text { Mission }\end{array}$ & $\begin{array}{l}\text { Jan- } \\
1998 \\
\text { to } \\
\text { Dec- } \\
2012\end{array}$ & $\begin{array}{l}\text { Daily } \\
\text { and } \\
\text { Monthly } \\
\text { Precipita } \\
\text { tion } \\
\text { (mm) }\end{array}$ & TRMM & $\begin{array}{l}\text { Huffman et al., } 2007 \\
\text { ftp://disc2.nascom.nasa.go } \\
\text { v/data/TRMM/Gridded/ }\end{array}$ & $\begin{array}{l}\text { Daily accumulated } \\
\text { (satellite derived) } \\
\text { output } \\
\quad 3 \mathrm{~B} 42 \text { Version } 7 \\
\quad\left(180^{\circ} \mathrm{W}-180^{\circ} \mathrm{E} \text {, }\right. \\
\left.\quad 50^{\circ} \mathrm{S}-50^{\circ} \mathrm{N}\right)\end{array}$ & 1998 onwards & $0.25^{\circ} \times 0.25^{\circ}$ \\
\hline $\begin{array}{l}\text { Climate } \\
\text { Prediction } \\
\text { Centre } \\
\text { Morphing }\end{array}$ & $\begin{array}{l}\text { Jan- } \\
1998 \\
\text { to } \\
\text { Dec- } \\
2012\end{array}$ & $\begin{array}{l}\text { Daily } \\
\text { and } \\
\text { Monthly } \\
\text { Precipita } \\
\text { tion } \\
(\mathrm{mm})\end{array}$ & $\begin{array}{l}\text { CMORP } \\
\mathrm{H}\end{array}$ & $\begin{array}{l}\text { Joyce et al., } 2004 \\
\text { ftp://ftp.cpc.ncep.noaa.go } \\
\text { v/precip/CMORPH_V1.0/ } \\
\text { CRT/ }\end{array}$ & $\begin{array}{l}\text { Gauge and satellite } \\
\text { blended precipitation } \\
\text { data (Version 1.0) }\end{array}$ & 1998 onwards & $0.25^{\circ} \times 0.25^{\circ}$ \\
\hline $\begin{array}{l}\text { Global } \\
\text { Precipitati } \\
\text { on } \\
\text { Climatolog } \\
\text { y Project }\end{array}$ & $\begin{array}{l}\text { Jan- } \\
1979 \\
\text { to Jun- } \\
2009\end{array}$ & $\begin{array}{l}\text { Monthly } \\
\text { Precipita } \\
\text { tion } \\
(\mathrm{mm})\end{array}$ & GPCP & $\begin{array}{l}\text { Adler et al., } 2003 \\
\text { http://www.esrl.noaa.gov/ } \\
\text { psd/data/gridded/data.gpc } \\
\text { p.html }\end{array}$ & $\begin{array}{l}\text { Combines station } \\
\text { and satellite } \\
\text { precipitation data }\end{array}$ & 1979 onwards & $2.5^{\circ} \times 2.5^{\circ}$ \\
\hline $\begin{array}{l}\text { India } \\
\text { Meteorolo } \\
\text { gical } \\
\text { Departmen } \\
\text { t station } \\
\text { data for } \\
\text { Leh }\end{array}$ & $\begin{array}{l}\text { Mar- } \\
1978 \\
\text { to } \\
\text { Mar- } \\
1990 \\
\text { (Missi } \\
\text { ng } \\
\text { Data } \\
\text { Jan- } \\
1988 \\
\text { to } \\
\text { Nov- }\end{array}$ & $\begin{array}{l}\text { Daily } \\
\text { and } \\
\text { Monthly } \\
\text { Precipita } \\
\text { tion } \\
\text { (mm) }\end{array}$ & IMDS & $\begin{array}{l}\text { India Meteorological } \\
\text { Department }\end{array}$ & & & \\
\hline
\end{tabular}




\begin{tabular}{|c|c|c|c|c|c|c|c|}
\hline & 1988) & & & & & & \\
\hline $\begin{array}{l}\text { Global } \\
\text { Precipitati } \\
\text { on } \\
\text { Climatolog } \\
\text { y Centre }\end{array}$ & $\begin{array}{l}\text { Jan- } \\
1901 \\
\text { to } \\
\text { Dec- } \\
2010\end{array}$ & $\begin{array}{l}\text { Monthly } \\
\text { Precipita } \\
\text { tion } \\
(\mathrm{mm})\end{array}$ & GPCC & $\begin{array}{l}\text { Schneider et al., } 2011 \\
\text { http://www.esrl.noaa.gov/ } \\
\text { psd/data/gridded/data.gpc } \\
\text { c.html }\end{array}$ & $\begin{array}{l}\text { Derived from global } \\
\text { station data (version } \\
6.0 \text { ) }\end{array}$ & 1901 onwards & $0.5^{\circ} \times 0.5^{\circ}$ \\
\hline
\end{tabular}


Table 2: Correlation between different datasets for (a) monthly temperature dataset from 1979 to 2009 and (b) monthly precipitation datasets for common years between datasets. Highlighted cells show relatively higher correlation ( $>$ 0.5) between different observational datasets. (* denotes no correlation calculated due to lack of common time series data.)

\begin{tabular}{|c|c|c|c|c|}
\hline (a) & ERA & CRU & NNRP & IMDST \\
\hline ERA & 1.000 & & & \\
\hline CRU & 0.990 & 1.000 & & \\
\hline NNRP & 0.985 & 0.980 & 1.000 & \\
\hline IMDST & 0.994 & 0.993 & 0.981 & 1.000 \\
\hline
\end{tabular}

\begin{tabular}{|c|c|c|c|c|c|c|c|c|}
\hline (b) & APHRO & AIRFORCE & GPCP & IMDG & GPCC & TRMM & CMORPH & IMDS \\
\hline APHRO & 1.000 & & & & & & & \\
\hline AIRFORCE & 0.384 & 1.000 & & & & & & \\
\hline GPCP & 0.633 & 0.488 & 1.000 & & & & & \\
\hline IMDG & 0.509 & 0.254 & 0.492 & 1.000 & & & & \\
\hline GPCC & 0.529 & 0.436 & 0.651 & 0.548 & 1.000 & & & \\
\hline TRMM & 0.130 & 0.347 & 0.631 & 0.102 & 0.436 & 1.000 & & \\
\hline CMORPH & 0.084 & 0.205 & 0.269 & -0.046 & 0.114 & 0.272 & 1.000 & \\
\hline IMDS & 0.461 & 0.905 & 0.417 & 0.328 & 0.333 & $*$ & $*$ & 1.000 \\
\hline
\end{tabular}


Table 3: Mann-Kendall test analysis showing Kendall's tau factor, P-value and Kendall's score for (a) temperature annually and seasonally (DJFM, AMJ, JAS and ON), (b) precipitation annually and seasonally (DJFM, AMJ, JAS and ON), (c) temperature monthly time series analysis for 1901-1978, 1979-1991 and 1992-2013, (d) precipitation monthly time series analysis for 1901-1969, 1970-1995 and 1996-2013, (e) no. of days greater than +1SD (GT_1SD) and +2SD (GT_2SD) in an year, all represented with the available datasets. Grey shaded cells are with P-value less than 0.05 . * Denotes where data is not available.

\begin{tabular}{|c|c|c|c|c|c|c|c|c|c|c|c|c|c|c|c|}
\hline \multirow[b]{2}{*}{ (a) } & \multicolumn{3}{|c|}{ ANNUAL } & \multicolumn{3}{|c|}{ DJFM } & \multicolumn{3}{|c|}{ AMJ } & \multicolumn{3}{|c|}{ JAS } & \multicolumn{3}{|c|}{ ON } \\
\hline & $\begin{array}{l}\text { Kenda } \\
\text { ll Tau }\end{array}$ & $\begin{array}{c}\text { P- } \\
\text { Value }\end{array}$ & $\begin{array}{c}\text { Kenda } \\
\text { Il } \\
\text { Score }\end{array}$ & $\begin{array}{l}\text { Kenda } \\
\text { ll Tau }\end{array}$ & $\begin{array}{c}\text { P- } \\
\text { Value }\end{array}$ & $\begin{array}{c}\text { Kenda } \\
\text { Il } \\
\text { Score } \\
\end{array}$ & $\begin{array}{l}\text { Kenda } \\
\text { ll Tau }\end{array}$ & $\begin{array}{c}\text { P- } \\
\text { Value }\end{array}$ & $\begin{array}{c}\text { Kenda } \\
\text { Il } \\
\text { Score } \\
\end{array}$ & $\begin{array}{l}\text { Kenda } \\
\text { ll Tau }\end{array}$ & $\begin{array}{c}\text { P- } \\
\text { Value }\end{array}$ & $\begin{array}{c}\text { Kenda } \\
\text { Il } \\
\text { Score } \\
\end{array}$ & $\begin{array}{l}\text { Kenda } \\
\text { ll Tau }\end{array}$ & $\begin{array}{c}\text { P- } \\
\text { Value }\end{array}$ & $\begin{array}{c}\text { Kenda } \\
\text { Il } \\
\text { Score }\end{array}$ \\
\hline ERA & 0.3784 & 0.0010 & 252 & 0.2672 & 0.0248 & 159 & 0.2874 & 0.0158 & 171 & 0.4189 & 0.0005 & 235 & 0.2478 & 0.0408 & 139 \\
\hline CRU & 0.4086 & 0.0000 & 2490 & 0.4300 & 0.0000 & 2570 & 0.2110 & 0.0012 & 1235 & 0.2132 & 0.0011 & 1242 & 0.3509 & 0.0000 & 2050 \\
\hline NNRP & 0.1589 & 0.0560 & 362 & 0.2112 & 0.0124 & 453 & 0.1198 & 0.1566 & 257 & $\begin{array}{c}- \\
0.1879\end{array}$ & 0.0261 & -403 & 0.0779 & 0.3620 & 162 \\
\hline IMDST & $\begin{array}{c}- \\
0.1531\end{array}$ & 0.4573 & -16 & 0.1026 & 0.6693 & 8 & $\begin{array}{c}- \\
0.2424\end{array}$ & 0.3037 & -16 & $\begin{array}{c}- \\
0.3030\end{array}$ & 0.1926 & -20 & $\begin{array}{c}- \\
0.2121\end{array}$ & 0.3727 & -14 \\
\hline
\end{tabular}

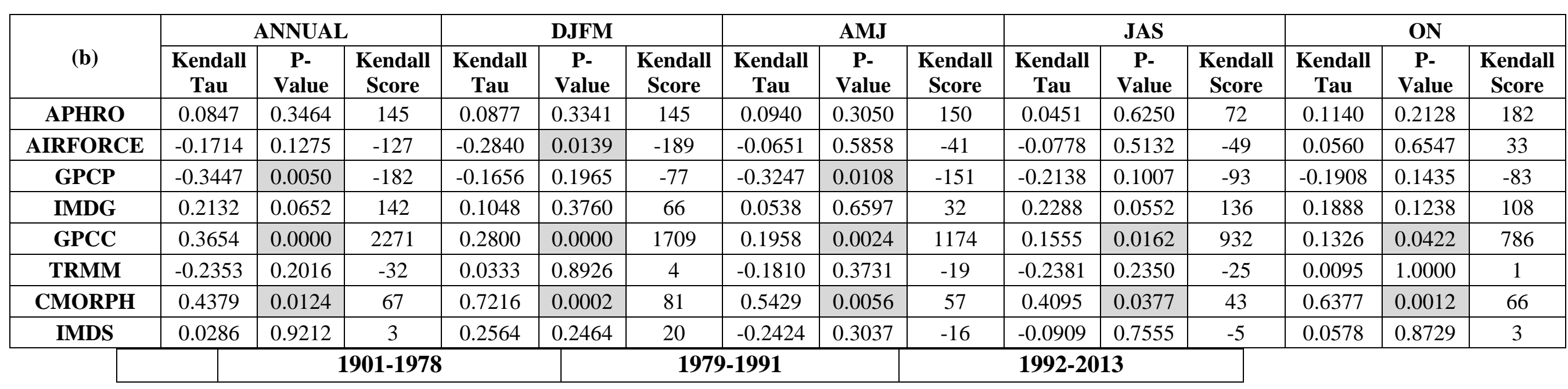




\begin{tabular}{|l|c|c|c|c|c|c|c|c|c|}
\hline (c) & $\begin{array}{c}\text { Kendall } \\
\text { Tau }\end{array}$ & $\begin{array}{c}\text { P- } \\
\text { Value }\end{array}$ & $\begin{array}{c}\text { Kendal } \\
\text { Score }\end{array}$ & $\begin{array}{c}\text { Kendall } \\
\text { Tau }\end{array}$ & $\begin{array}{c}\text { P- } \\
\text { Value }\end{array}$ & $\begin{array}{c}\text { Kendal } \\
\text { Score }\end{array}$ & $\begin{array}{c}\text { Kendall } \\
\text { Tau }\end{array}$ & $\begin{array}{c}\text { P- } \\
\text { Value }\end{array}$ & $\begin{array}{c}\text { Kendal } \\
\text { Score }\end{array}$ \\
\hline ERA & $*$ & $*$ & $*$ & 0.0275 & 0.6109 & 333 & 0.0335 & 0.4226 & 1112 \\
\hline CRU & 0.0248 & 0.0256 & 10838 & 0.0201 & 0.7119 & 242 & 0.0581 & 0.2049 & 1347 \\
\hline NNRP & -0.0137 & 0.6933 & -946 & 0.0151 & 0.7815 & 182 & 0.0785 & 0.0395 & 2642 \\
\hline IMDST & -0.1111 & 0.7205 & -5 & -0.0202 & 0.0431 & -154 & $*$ & $*$ & $*$ \\
\hline
\end{tabular}

\begin{tabular}{|c|c|c|c|c|c|c|c|c|c|}
\hline \multirow{2}{*}{$(\mathrm{d})$} & \multicolumn{3}{|c|}{$\mathbf{1 9 0 1 - 1 9 6 9}$} & \multicolumn{3}{c|}{$\mathbf{1 9 7 0 - 1 9 9 5}$} & \multicolumn{3}{c|}{$\mathbf{1 9 9 6 - 2 0 1 3}$} \\
\cline { 2 - 10 } & $\begin{array}{c}\text { Kendall } \\
\text { Tau }\end{array}$ & $\begin{array}{c}\text { P- } \\
\text { Value }\end{array}$ & $\begin{array}{c}\text { Kendal } \\
\text { Score }\end{array}$ & $\begin{array}{c}\text { Kendall } \\
\text { Tau }\end{array}$ & $\begin{array}{c}\text { P- } \\
\text { Value }\end{array}$ & $\begin{array}{c}\text { Kendal } \\
\text { Score }\end{array}$ & $\begin{array}{c}\text { Kendall } \\
\text { Tau }\end{array}$ & $\begin{array}{c}\text { P- } \\
\text { Value }\end{array}$ & $\begin{array}{c}\text { Kendal } \\
\text { Score }\end{array}$ \\
\hline APHRO & -0.3034 & 0.0000 & -7849 & 0.1260 & 0.0009 & 6114 & -0.0314 & 0.5781 & -323 \\
\hline AIRFORCE & $*$ & $*$ & $*$ & 0.0540 & 0.1929 & 1981 & -0.0856 & 0.1263 & -955 \\
\hline GPCP & $*$ & $*$ & $*$ & 0.0021 & 0.9648 & 44 & -0.0704 & 0.03841 & -978 \\
\hline IMDG & $*$ & $*$ & $*$ & 0.2997 & 0.0000 & 13196 & -0.1874 & 0.0034 & -1272 \\
\hline GPCC & -0.0464 & 0.0469 & -15791 & 0.1051 & 0.0099 & 4482 & 0.0124 & 0.8176 & 179 \\
\hline TRMM & $*$ & $*$ & $*$ & $*$ & $*$ & $*$ & -0.0253 & 0.6163 & -406 \\
\hline CMORPH & $*$ & $*$ & $*$ & $*$ & $*$ & $*$ & 0.3777 & 0.0602 & 752 \\
\hline IMDS & $*$ & $*$ & $*$ & 0.0420 & 0.4854 & 360 & $*$ & $*$ & $*$ \\
\hline
\end{tabular}

\begin{tabular}{|c|c|c|c|c|c|c|}
\hline \multirow{2}{*}{$(\mathbf{e})$} & \multicolumn{3}{|c|}{ GT_1SD } & \multicolumn{2}{c|}{ GT_2SD } \\
\cline { 2 - 7 } & Kendall Tau & P-Value & Kendall Score & Kendall Tau & P-Value & Kendall Score \\
\hline IMDG & -0.0271 & 0.8311 & -16 & 0.0086 & 0.9545 & 5 \\
\hline APHRO & 0.1597 & 0.0837 & 252 & 0.0601 & 0.5248 & 93 \\
\hline TRMM & -0.4261 & 0.0357 & -43 & -0.3468 & 0.0887 & -35 \\
\hline CMORPH & 0.2789 & 0.1648 & 29 & 0.0518 & 0.8202 & 6 \\
\hline IMDS & -0.5002 & 0.0228 & -38 & -0.3530 & 0.1107 & -27 \\
\hline
\end{tabular}

